\title{
TIPE KESALAHAN NEWMAN PADA HASIL PENGUKURAN
}

\author{
Nursupiamin ${ }^{1)}$ \\ e-mail: nursupia@gmail.com
}

1Dosen Fakultas Tarbiyah Ilmu Keguruan Institut Agama Islam Negeri Palu

\begin{abstract}
The command of learning in the Qur'an aims to enable people to gain knowledge, experience, and learning in living life, especially in overcoming the problems encountered. Mathematics is a branch of science that plays an important role in life whose application is seen in various disciplines. Measurement material is one of the subjects of Mathematics I taught in the Madrasah Ibtidaiyah Teacher Education Study Program (PGMI) semester V. The results of individual assignments show that the scores obtained are not optimal yet there are still many errors in completion. In this study, the authors used the Newman procedure error approach. Based on the results of the study, the percentage of reading errors reached $24.5 \%$, understanding errors $17.6 \%$, transformation errors $15.6 \%$, processing skills errors $16.6 \%$ and answers writing errors $25.7 \%$. The results of the interview show that reading errors are generally caused by incompetence in writing words / symbols due to factors that forget or do not know in standard writing. Misunderstanding is caused by students having difficulty understanding the phrase "standard unit writing", consequently also difficulty in determining the final result. Transformation errors are caused by errors in converting to standard units and errors for process skills are due to inaccuracy in writing answers so that they experience calculation errors that also have an impact on writing the final result. Finally, the answer writing error is caused by inaccuracy in writing the final answer caused by other types of mistakes made previously.
\end{abstract}

Keywords: Newman Type errors, Measurements

\section{PENDAHULUAN}

Al-Qur'an secara jelas mengisyaratkan perintah Allah swt kepada umat manusia untuk senantiasa belajar baik melalui membaca maupun menulis. Sebagaimana tertera pada Q.S. Al- Alaq/96 : 1-5. Isyarat tersebut bertujuan agar manusia mendapatkan pengetahuan, pengalaman, pembelajaran dan sebagainya dalam menjalani kehidupan dan dalam mengatasi persoalan yang dihadapi. Berdasarkan hal tersebut, pendidikan tentunya tidak hanya memandang pencapaian hasil akhir berupa hasil belajar, akan tetapi juga memandang proses belajar yang terjadi pada diri peserta didik dan niat atau kemauan untuk belajar.

Matematika merupakan salah satu cabang ilmu yang memiliki peranan penting dalam kehidupan manusia. Sebagai ilmu universal, matematika banyak digunakan dalam berbagai disiplin dan memajukan daya pikir manusia. Sriyanto 
menuliskan matematika berasal dari kata mathematikos yang berarti suka belajar. ${ }^{1}$ Makna ini menunjukkan tidak ada alasan untuk tidak menyukai atau bahkan takut untuk belajar matematika. Akan tetapi kontradiksi dengan kenyataan banyak orang yang kurang menyukai matematika.

Ketidaksenangan pada sesuatu tentu berkaitan erat dengan kesalahan yang mungkin dilakukan atau takut melakukan kesalahan. Ketidaksenangan dapat dipandang sebagai dampak dari kesalahan yang dilakukan. Jika kesalahan dapat diminimalkan tentu ketidaksenangan juga dapat diminimalkan. Kesalahan dalam Kamus Besar Bahasa Indonesia (KBBI) diartikan sebagai perihal salah, kekeliruan, kealpaan atau tidak sengaja berbuat sesuatu. ${ }^{2}$ Salah satu penyebab seseorang melakukan kesalahan adalah kurangnya penguasaan. Nurussafa'at, dkk mengemukakan bahwa kesalahan yang dilakukan peserta didik dalam mengerjakan soal cerita perlu dianalisis lebih lanjut untuk mendapatkan gambaran yang jelas dan rinci atas kelemahan-kelemahan peserta didik. ${ }^{3}$

Materi Pengukuran merupakan salah satu pokok bahasan pada mata kuliah Matematika I yang diajarkan di Jurusan Pendidikan Guru Madrasah Ibtidaiyah (PGMI) semester V. Adapun kompetensi yang ingin dicapat pada materi ini adalah mahasiswa mampu memahami konsep pengukuran sudut, panjang, berat, satuan waktu, kecepatan, dan kecepatan air (debit air). Selama proses perkuliahan berlangsung terlihat mahasiswa sudah mampu mengenal konsep dasar pengukuran, akan tetapi dalam hasil penugasan yang dilakukan secara individu di lapangan terlihat belum maksimalnya nilai yang diperoleh dari tugas tersebut sehingga terdapat kesalahan dalam penyelesaiannya.

Pada penelitian ini, penulis menggunakan pendekatan kesalahan menurut prosedur Newman. Metode analisis kesalahan Newman diperkenalkan pertama kali pada tahun 1977 oleh Anne Newman. Prosedur Newman adalah sebuah metode untuk menganalisis kesalahan dalam soal uraian. Langkah-langkah yang harus dilakukan untuk menyelesaikan soal matematika menurut Newman yaitu membaca soal (reading), memahami masalah (comprehension), transformasi (transformation), keterampilan proses (process skill), dan penulisan jawaban (encoding). ${ }^{4}$

Berdasarkan latar belakang tersebut penulis fokuskan penelitian ini melihat tipe kesalahan Newman dalam menyelesaikan soal pengukuran. Sehingga tujuan penelitian adalah untuk menganalisis tipe kesalahan Newman dalam penyelesaian soal pengukuran. Adapun manfaat yang diharapkan dari penelitian ini meliputi manfaat teoritis dan manfaat praktis. Manfaat teoritisnya adalah dapat menambah dan memperkaya ilmu pengetahuan dalam bidang pengajaran matematika khususnya

1 H.J. Sriyanto, Strategi Sukses Mengenai Matematika, (Cet:I, Yogyakarta: Indonesia Cerdas, 2007), h. 12.

2 https://kbbi.kemdikbud.go.id/entri/Kesalahan

3 Fitri Andika Nurussafa'at, Imam Sujadi, dan Riyadi. 2016. Analisis Kesalahan Siswa Dalam Menyelesaikan Soal Cerita pada Materi Volume Prisma dengan Fong's Shcematic Model For Error Analysis Ditinjau dari Gaya Kognitif Siswa. Jurnal Elektronik Pembelajaran Matematika, 4(2); 174-187. (diakses 24 Oktober 2019).

4'wan Darmawan, Anis Kharismawati, Heris Hendriana, dan Ratni Purwasih. 2018. Analisis Kesalahan Siswa SMP Berdasarkan Newman dalam Menyelesaikan Soal Kemampuan Berpikir Kritis Matematis pada Materi Bangun Ruang Sisi datar. Juring (Journal for Research in Mathematics Learning), 1(1); 71-78. (diakses 24 Oktober 2019). 
berkaitan dengan analisis kesalahan Newman. Sedangkan manfaat praktisnya adalah dapat memberikan sumbangan ilmiah dalam meningkatkan aspek-aspek yang dapat meningkatkan pemahaman mahasiswa, dan memberikan informasi kepada pembaca tentang gambaran tipe kesalahan Newman yang dilakukan mahasiswa dalam menyelesaikan soal pengukuran.

Penelitian terdahulu yang relevan dengan penelitian ini antara lain :

1. Penelitian yang dilakukan oleh Ida Karnasih, pada tahun 2015 yang berjudul "Analisis kesalahan Newman pada soal cerita matematis (Newman's Error Analysis in Mathematical Word Problems)" yang menyimpulkan bahwa: Penerapan NEA di sekolah-sekolah di Luar Negeri telah menunjukkan hasil positif dalam meningkatkan kemampuan siswa memecahkan masalah soal cerita (word problems). Hasil beberapa penelitian dalam menerapkan NEA di Australia menunjukkan kesuksesan dalam meningkatkan kompetensi baik guru dan hasil belajar siswa. Data hasil analisis statistik menunjukkan peningkatan secara signifikan pada hasil antara pengetahuan awal dan pengetahuan setelah penyelesaian program yang melibatkan pemecahan masalah menggunakan masalah soal cerita dalam belajar matematika. Selain NEA telah digunakan oleh para guru sebagai strategi pembelajaran kelas remedial. NEA dipakai juga sebagai strategi pedagogis untuk kelas yang lebih luas. Dapat disimpulkan bahwa penerapan NEA dalam pengajaran dapat menjadi alat diagnostik yang kuat untuk menilai dan menganalisis kesulitan siswa yang mengalami masalah dalam menyelesaikan soal cerita matematis. ${ }^{5}$

2. Kajian yang dilakukan oleh Iwan Darmawan dkk pada tahun 2018 yang berjudul "Analisis Kesalahan Siswa SMP Berdasarkan Newman dalam Menyelesaikan Soal Kemampuan Berpikir Kritis Matematis pada Materi Bangun Ruang Sisi datar". Adapun hasil kajian tersebut menunjukkan bahwa : kesalahan yang dilakukan siswa dalam 6 aspek yaitu kesalahan membaca soal (reading errors), kesalahan memahami masalah (comprehension errors), kesalahan transformasi (transformation errors), kesalahan keterampilan proses (process skills errors), dan kesalahan penulisan jawaban (encoding errors) serta kesalahan kecerobohan (careless errors). ${ }^{6}$

Tujuan utama penulis melakukan analisis kesalahan tipe Newman terhadap hasil mahasiswa dalam menyelesaikan soal pengukuran adalah agar mahasiswa mengetahui jenis dan letak kesalahan yang dilakukan sehingga mahasiswa dalam menyelesaikan soal pengukuran sesuai prosedur yang ditentukan. Analisis kesalahan merupakan salah satu upaya menyelidiki penyimpangan, pelanggaran, dan kekeliruan (kekhilafan) yang terjadi pada suatu persoalan terhadap suatu kaidah, norma atau aturan yang telah ditentukan.

Metode analisis kesalahan Newman diperkenalkan pertama kali pada tahun 1977 oleh Anne Newman, seorang guru bidang studi matematika di Australia. Dalam metode ini, Anne Newman menyarankan lima kegiatan yang spesifik sebagai suatu yang sangat krusial untuk membantu menemukan di mana kesalahan yang terjadi pada pekerjaan peserta didik ketika menyelesaikan suatu masalah berbentuk soal

5 Ida Karnasih. 2015. Analisis Kesalahan Newman Pada Soal Cerita Matematis (Newman's Error Analysis In Mathematical Word Problems). Jurnal PARADIKMA, 8(1); 37-51

${ }^{6}$ Iwan Darmawan, Anis Kharismawati, Heris Hendriana, dan Ratni Purwasih. 
cerita. Prosedur Newman adalah sebuah metode untuk menganalisis kesalahan dalam soal uraian. Langkah-langkah yang harus dilakukan untuk menyelesaikan soal matematika menurut Newman yaitu membaca soal (reading), memahami masalah (comprehension), transformasi (transformation), keterampilan proses (process skill), dan penulisan jawaban (encoding). ${ }^{7}$

Prakitipong dan Nakamura menuliskan prosedur Newman merupakan metode menganalisis kesalahan dalam soal cerita. Dalam proses pemecahan masalah, terdapat beberapa faktor yang mendukung peserta didik untuk memberikan jawaban yang benar sesuai prosedur yang ditentukan. Metode ini mengandaikan bahwa dalam proses pemecahan masalah ada dua jenis hambatan yang menghalangi peserta didik mendapatkan jawaban yang benar: (1) Masalah dalam kelancaran linguistik dan pemahaman konseptual yang sesuai dengan tingkat membaca sederhana dan memahami makna masalah, dan (2) Masalah dalam pengolahan matematika yang terdiri dari transformasi, keterampilan proses, dan jawaban encoding. Klasifikasi ini menyiratkan bahwa peserta didik harus menafsirkan makna pertanyaan dalam konteks matematika sebelum melanjutkan ke pengolahan matematika untuk mendapatkan jawaban yang sesuai. ${ }^{8}$

Jha menuliskan kelima tingkatan dalam prosedur Newman dengan membahasakan lebih sederhana, yaitu :

Tingkat I. Membaca : Dapatkah peserta didik membaca pertanyaan?

Tingkat II. Pemahaman : Dapatkah peserta didik memahami maksud pertanyaan?

Tingkat III. Transformasi : Dapatkah peserta didik mennetukan operasi atau prosedur matematika yang sesuai?

Tingkat IV. Keterampilan Proses : Dapatkah peserta didik melakukan perhitungan matematika dengan sempurna?

Tingkat V. Penulisan Jawaban : Dapatkah peserta didik memberikan jawaban yang benar? ${ }^{9}$

Kelima tingkatan tersebut sesuai dengan tingkatan konseptual prosedur Newman menurut Prakitipong dan Nakamura. Dengan menambahkan penjelasan di masing-masing tingkatan, yaitu :

1. Tingkat membaca berupa pengenalan kata dan simbol sederhana

2. Tingkat pemahaman lebih khusus ke pemahaman linguistik masalah

3. Tingkat transformasi menunjukkan tahapan transformasi dari pemahaman linguistik ke interpretasi matematis

4. Tingkat keterampilan proses menekankan pada eksekusi pengolahan matematika.

5. Tingkat Penulisan Jawaban terfokus pada representasi hasil dari pemrosesan matematika. ${ }^{10}$

7 Ibid.

${ }^{8}$ Natcha Prakitipong and Satoshi Nakamura. 2006. Analysis of Mathematics Performance of Grade Five Students in Thailand Using Newman Procedure. Journal of International Cooperation in Education, 9(1); 111-122.

9 Shio Kumar Jha. 2012. Mathematics Performance of Primary School Students in Assam (India): An Analysis Using Newman Procedure. International Journal of Computer Applications in Engineering Sciences, 2(1); 17-21.

10 Natcha Prakitipong and Satoshi Nakamura. 
Parmjit Singh, Arba Abdul Rahman, dan Teoh Sian Hoon dalam kajiannya ternyata menemukan 7 jenis kesalahan yang merupakan pengembangan dari jenis kesalahan tipe Newman, yaitu :

1. Kesalahan Membaca, terjadi ketika kata-kata atau simbol ditulis dengan tidak sempurna sehingga sulit dikenali yang menyebabkan kegagalannya untuk menuliskan penyelesaian masalah.

2. Kesalahan Pemahaman, terjadi ketika dapat membaca pertanyaan tetapi gagal untuk memahami syaratnya, sehingga menyebabkan salah atau gagal dalam memecahkan masalah.

3. Kesalahan Transformasi, terjadi ketika peserta didik benar memahami persyaratan pertanyaan tetapi gagal mengidentifikasi operasi matematika yang tepat atau urutan penggunaan operasi dalam setiap langkah penyelesaian masalah.

4. Kesalahan Keterampilan Proses, terjadi ketika peserta didik gagal dalam mengerjakan persoalan sesuai prosedur yang benar meskipun berhasil mengidentifikasi operasi matematika yang tepat atau urutan penggunaan operasi dalam penyelesaian masalah.

5. Kesalahan Penulisan Jawaban, terjadi ketika peserta didik gagal memberikan bentuk jawaban tertulis yang dapat diterima, meskipun telah menyelesaikan tugas matematika dengan tepat dan benar.

6. Kesalahan Kecerobohan, terdeteksi ketika peserta didik salah dalam mengerjakan tugas secara tertulis tetapi secara lisan mampu memberikan jawaban yang benar.

7. Argumen yang Cacat, terjadi ketika peserta didik mendapat jawaban yang benar meskipun telah salah menafsirkan persyaratan pertanyaan dan/atau melakukan kesalahan selama proses penyelesaian masalahnya. ${ }^{11}$

Dengan demikian, melalui tipe kesalahan Newman peserta didik berusaha menjawab permasalahan dalam bentuk soal cerita dan menempuh rintanganrintangan sebagai langkah dalam pemecahan masalah.

\section{METODE}

Penelitian ini dilaksanakan di IAIN Palu pada semester ganjil tahun akademik 2019/2020. Jenis penelitian yang digunakan adalah penelitian deskriptif. Penelitian deskriptif bertujuan untuk memaparkan dan menggambarkan fakta-fakta berdasarkan cara pandang tertentu. ${ }^{12}$ Teknik pemilihan subjek penelitian menggunakan purposive sample dengan subjek penelitian mahasiswa Prodi PGMI Semester V kelas 2 berjumlah 18 orang. Instrumen penelitian yang digunakan untuk mengumpulkan data

11 Parmjit Singh, Arba Abdul Rahman, and Teoh Sian Hoon. 2010. The Newman Procedure for Analyzing Primary Four Pupils Errors on Written Mathematical Task: A Malaysian Perspective". Procedia on Internaional Conference on Mathematics Education Research 2010 (ICMER 2010). Procedia Social and Behavioral Sciences 8 (2010); 264-271. Shah Alam: University Technology MARA.

12 Dwi Oktaviana. 2017. Analisis Tipe Kesalahan Berdasarkan Teori Newman Dalam Menyelesaikan Soal Cerita Pada Mata Kuliah Matematika Diskrit. EduSains: Jurnal Pendidikan Sains \& Matematika, 5(2); 22-32 
adalah berupa tes, dokumentasi dan pedoman wawancara. Tes diberikan kepada mahasiswa berupa tes soal cerita terkait materi pengukuran. Tes terdiri dari 6 soal essay yang masing-masing soal cerita untuk mengukur pemahaman konsep pengukuran sudut, panjang, berat, satuan waktu, kecepatan, dan kecepatan air (debit air). Berdasarkan hasil jawaban tes dilakukan wawancara untuk melakukan triangulasi dari data yang diperoleh. Analisis data dilakukan dengan reduksi data, penyajian data, dan penarikan kesimpulan.

\section{PEMBAHASAN}

Dalam penelitian ini, peneliti memberikan tes terbuka kepada subyek penelitian berkaitan dengan materi pengukuran untuk dikerjakan secara individu. Adapun soal terbuka tersebut berbunyi : "Berikan masing-masing 1 contoh percobaan hasil pengukuran dengan menggunakan 6 alat ukur (sudut, panjang/jarak, berat, waktu, kecepatan, dan debit air). Dokumentasikan percobaannya dan tuliskan hasil akhir pengukuran dalam satuan baku!"'. Soal tersebut memiliki total nilai 50 untuk masing-masing hasil pengukuran dengan rincian penilaian setiap aspek bernilai 10. Aspek penilaian untuk penyelesaian tugas tersebut mencakup : (1) percobaan pengukuran (kreatifitas mahasiswa dalam membuat contoh sederhana melalui dokumentasi); (2) penunjukan hasil pengukuran (juga diperlihatkan melalui hasil dokumentasi); (3) dokumentasi keaslian pengukuran (tidak ada dokumentasi yang sama atau mirip dengan mahasiswa lain); (4) penulisan hasil pengukuran dalam bentuk satuan baku; dan (5) penulisan penyelesaian secara terperinci (termasuk penyusunan dokumentasi dan narasi hasil pengukuran).

Berdasarkan aspek penilaian tersebut diperoleh gambaran kesalahan tipe Newman yang dilakukan dapat dilihat pada tabel berikut:

Tabel 1: Persentase Perolehan Kesalahan Tipe Newman dalam Menyelesaikan Soal Pengukuran

\begin{tabular}{|c|c|c|c|c|}
\hline \multicolumn{5}{|c|}{ Tipe Kesalahan Newman (\%) } \\
\hline Membaca & Pemahaman & Transformasi & $\begin{array}{c}\text { Keterampilan } \\
\text { Proses }\end{array}$ & $\begin{array}{c}\text { Penulisan } \\
\text { Jawaban }\end{array}$ \\
\hline 24,5 & 17,6 & 15,6 & 16,6 & 25,7 \\
\hline
\end{tabular}

Sumber : Olah Data Tanggal 10 November 2019

Adapun gambaran karakteristik distribusi skor kesalahan selengkapnya dapat dilihat dari tabel berikut:

Tabel 2 : Deskripsi Kesalahan Tipe Newman dalam Menyelesaikan Soal Pengukuran

\begin{tabular}{|l|r|r|r|r|r|}
\hline & Membaca & Pemahaman & Transformasi & $\begin{array}{c}\text { Ketrampilan } \\
\text { Proses }\end{array}$ & $\begin{array}{c}\text { Penulisan } \\
\text { Jawaban }\end{array}$ \\
\hline N Valid & 18 & 18 & 18 & 18 & 18 \\
Missing & 0 & 0 & 0 & 0 & 0 \\
Mean & 6.7222 & 4.8333 & 4.2778 & 4.5556 & 7.0556 \\
Minimum & .00 & .00 & .00 & .00 & 2.00
\end{tabular}




\begin{tabular}{|l|r|r|r|r|r|} 
Maximum & 17.00 & 12.00 & 10.00 & 10.00 & 14.00 \\
Sum & 121.00 & 87.00 & 77.00 & 82.00 & 127.00 \\
\hline
\end{tabular}

Sumber : Olah Data Tanggal 10 November 2019

Berdasarkan tabel 2 menunjukkan bahwa terdapat mahasiswa yang tidak melakukan kesalahan tingkat membaca, pemahaman, transformasi, dan keterampilan proses. Sedangkan untuk kesalahan penulisan jawaban terdapat mahasiswa mendapatkan skor kesalahan minimal yaitu 2 . dilakukan.

Berikut gambaran kesalahan tipe Newman yang dominan dan paling sedikit

Tabel 3 : Deskripsi Kesalahan Tipe Newman yang Dilakukan Peserta Didik

\begin{tabular}{|l|c|c|}
\hline \multirow{2}{*}{ Tipe Kesalahan } & \multicolumn{2}{c|}{ Jumlah Mahasiswa yang Melakukan Kesalahan } \\
\cline { 2 - 3 } & Maksimal & Minimal \\
\hline Membaca & 9 & 5 \\
\hline Pemahaman & 1 & 4 \\
\hline Transformasi & 6 & 8 \\
\hline Keterampilan Proses & 1 & 7 \\
\hline Penulisan Jawaban & 8 & 1 \\
\hline
\end{tabular}

Tabel 3 menjelaskan banyak mahasiswa cenderung melakukan kesalahan membaca dan penulisan jawaban. Sedangkan dari tabel yang sama juga menunjukkan sebagian besar mahasiswa sudah cukup mampu dalam aspek pemahaman dan keterampilan proses.

Selanjutnya berikut dipaparkan gambaran kesalahan yang dominan dilakukan dan perolehan hasil wawancara.

1. Kesalahan Membaca.

Pada tingkat kesalahan ini, berdasarkan hasil wawancara dengan 9 orang mahasiswa yaitu FA, PA, RH, MF, WA, EL, IR, UK, dan RP menunjukkan secara umum disebabkan ketidaksempunaan dalam menuliskan kata/symbol yang disebabkan karena faktor lupa dan tidak tau dalam penulisan yang baku. Selain itu, faktor lainnya kurang memahami makna soal dan mengalami kebingungan pada saat melakukan percobaan pengukuran.

2. Kesalahan Pemahaman

Pada tingkat kesalahan ini, hanya terdapat seorang mahasiswa yaitu SL yang melakukan kesalahan pemahaman. Berdasarkan hasil wawancara diperoleh informasi, SL mengalami kesulitan dalam memahami kalimat "penulisan satuan baku". Akibatnya SL juga mengalami kesulitan dalam menentukan hasil akhir.

3. Kesalahan Transformasi

Pada tingkat kesalahan ini, terdapat 6 mahasiswa mengalaminya yaitu DD, NK, DL, UP, WA, dan SL. Berdasarkan hasil wawancara, secara umum disebabkan kesalahan dalam melakukan konversi (mengubah) ke satuan baku. Seperti kesalahan dalam mengubah $\mathrm{km} / \mathrm{jam} \mathrm{ke} \mathrm{m} / \mathrm{det}$.

4. Kesalahan Keterampilan Proses

Pada tingkat kesalahan ini, hanya terdapat seorang mahasiswa yaitu MJ yang melakukan kesalahan keterampilan proses. Berdasarkan hasil wawancara diperoleh informasi, MJ kurang teliti dalam menuliskan jawaban sehingga 
mengalami kesalahan perhitungan yang juga berdampak pada penulisan hasil akhir.

5. Kesalahan Penulisan Jawaban

Pada tingkat kesalahan ini, semua mahasiswa mengalami kesalahan ini. Akan tetapi yang dominan dialami oleh mahasiswa DD, DL, UP, WA, AI, NL, SN, dan SL. Berdasarkan hasil wawancara diperoleh informasi, mahasiswa kurang teliti dalam penulisan jawaban akhir yang disebabkan kesalahan-kesalahan tipe lain yang dilakukan sebelumnya.

\section{PENUTUP}

Berdasarkan hasil penelitian diperoleh informasi persentase kesalahan membaca mencapai $24,5 \%$, kesalahan pemahaman $17,6 \%$, kesalahan transformasi $15,6 \%$, kesalahan keterampilan proses $16,6 \%$ dan kesalahan penulisan jawaban $25,7 \%$. Dari perolehan tersebut terdapat mahasiswa yang tidak melakukan kesalahan tingkat membaca, pemahaman, transformasi, dan keterampilan proses. Sedangkan untuk kesalahan penulisan jawaban terdapat mahasiswa mendapatkan skor kesalahan minimal yaitu 2. Informasi lain yang diperoleh banyak mahasiswa cenderung melakukan kesalahan membaca dan penulisan jawaban sedangkan pada aspek pemahaman dan keterampilan proses sebagian besar mahasiswa sudah cukup mampu. Berdasarkan hasil wawancara diperoleh informasi bahwa kesalahan membaca umumnya disebabkan ketidaksempunaan dalam menuliskan kata/symbol karena faktor lupa atau tidak tau dalam penulisan yang baku. Selain itu, juga disebabkan kurang memahami makna soal sehingga mengalami kebingungan pada saat melakukan percobaan pengukuran. Pada kesalahan pemahaman mahasiswa mengalami kesulitan dalam memahami kalimat "penulisan satuan baku". Akibatnya juga mengalami kesulitan dalam menentukan hasil akhir. Pada kesalahan transformasi disebabkan kesalahan dalam melakukan konversi (mengubah) ke satuan baku. Seperti kesalahan dalam mengubah km/jam ke $\mathrm{m} /$ det. Untuk kesalahan keterampilan proses disebabkan kurang teliti dalam menuliskan jawaban sehingga mengalami kesalahan perhitungan yang juga berdampak pada penulisan hasil akhir. Dan kesalahan penulisan jawaban mahasiswa kurang teliti dalam penulisan jawaban akhir yang disebabkan kesalahan-kesalahan tipe lain yang dilakukan sebelumnya.

\section{DAFTAR PUSTAKA}

Darmawan, I., Kharismawati, A., Hendriana, H., dan Purwasih, R. 2018. Analisis Kesalahan Siswa SMP Berdasarkan Newman dalam Menyelesaikan Soal Kemampuan Berpikir Kritis Matematis pada Materi Bangun Ruang Sisi datar. Juring (Journal for Research in Mathematics Learning), 1(1); 7178. (diakses 24 Oktober 2019).

https://kbbi.kemdikbud.go.id/entri/Kesalahan

Jha, S.K. 2012. Mathematics Performance of Primary School Students in Assam (India): An Analysis Using Newman Procedure. International Journal of Computer Applications in Engineering Sciences, 2(1); 17-21. 
Karnasih, I. 2015. Analisis Kesalahan Newman Pada Soal Cerita Matematis (Newman's Error Analysis In Mathematical Word Problems). Jurnal PARADIKMA, 8(1); 37-51

Nurussafa'at., F.A., Sujadi, I., dan Riyadi. 2016. Analisis Kesalahan Siswa Dalam Menyelesaikan Soal Cerita pada Materi Volume Prisma dengan Fong's Shcematic Model For Error Analysis Ditinjau dari Gaya Kognitif Siswa. Jurnal Elektronik Pembelajaran Matematika, 4(2); 174-187. (diakses 24 Oktober 2019).

Oktaviana, D. 2017. Analisis Tipe Kesalahan Berdasarkan Teori Newman Dalam Menyelesaikan Soal Cerita Pada Mata Kuliah Matematika Diskrit. EduSains: Jurnal Pendidikan Sains \& Matematika, 5(2); 22-32

Prakitipong, N., and Nakamura, S. 2006. Analysis of Mathematics Performance of Grade Five Students in Thailand Using Newman Procedure. Journal of International Cooperation in Education, 9(1); 111-122.

Singh, P., Rahman, A.A., and Hoon, T.S. 2010. The Newman Procedure for Analyzing Primary Four Pupils Errors on Written Mathematical Task: A Malaysian Perspective". Procedia on Internaional Conference on Mathematics Education Research 2010 (ICMER 2010). Procedia Social and Behavioral Sciences 8 (2010); 264-271. Shah Alam: University Technology MARA

Sriyanto, H.J. Strategi Sukses Mengenai Matematika, Cet:I, Yogyakarta: Indonesia Cerdas, 2007. 